\title{
Effect of Various Chemical Herbicides on Nutrient uptake, Yield Attributes and Economics of Maize (Zea mays L.)
}

\author{
Arvind Kumar' ${ }^{1}$ S. S. Tomar' ${ }^{2}$, V. K. Verma ${ }^{3 *}$, Abhinav Kumar ${ }^{3}$ and R. K. Singh ${ }^{4}$ \\ ${ }^{1,2}$ Dept. of Agronomy, Sardar Vallabhbhai Patel University of Agriculture and Technology, Meerut, Uttar Pradesh (250 110), India \\ ${ }^{3-4}$ Dept. of Agronomy, Institute of Agricultural Sciences, B.H.U., Varanasi, Uttar Pradesh (221 005), India
}

\section{Article History}

Manuscript No. AR1694

Received in $21^{\text {st }}$ September, 2016

Received in revised form $24^{\text {th }}$ November, 2016

Accepted in final form $5^{\text {th }}$ December, 2016

\section{Correspondence to}

"E-mail: vermaagribhu@gmail.com

\section{Keywords}

Nutrient uptake, grain, stover and protein content

\begin{abstract}
A field experiment was conducted to assess the effect of chemical herbicides on nutrient uptake, yield and economics of maize (Zea mays L.) maize during kharif season of 2013 at the Crop Research Centre, Chirori of Sardar Vallabhbhai Patel University of Agriculture and Technology; Meerut, Uttar Pradesh (India). The results revealed that the among chemical methods of weed control, the maximum uptake of $\mathrm{N}$ and $\mathrm{P}$ in maize grains was observed with Alachlor+Metribuzin @ $750+375 \mathrm{~g} \mathrm{ha}^{-1}\left(\mathrm{~T}_{6}\right)$ and the maximum $\mathrm{K}$ uptake by maize grains was observed with Atrazine+Pendimethalin @ 750+500 $\mathrm{g} \mathrm{ha}^{-1}\left(\mathrm{~T}_{7}\right)$ and maximum N, P and K uptake in maize stover was observed with Atrazine+Pendimethalin @ 750+500 g ha ${ }^{-1}\left(\mathrm{~T}_{7}\right)$ along with grain yield $\left(\mathrm{q}\right.$ ha-1), stover yield $\left(\mathrm{q} \mathrm{ha}^{-1}\right)$ as well as harvest index, respectively. The minimum uptake of $\mathrm{N}, \mathrm{P}$ and $\mathrm{K}$ in maize grain and stover was observed under weedy check along with grain yield $\left(\mathrm{q} \mathrm{ha}^{-1}\right)$, stover yield $\left(\mathrm{q} \mathrm{ha} \mathrm{h}^{-1}\right)$ as well as harvest index, respectively. Protein content in maize grain found highest in weed free $\left(\mathrm{T}_{11}\right)$ (8.7\%). The higher dry weight, NPK content and uptake by weed under Atrazine +2 , 4-D @ 500+500 $\mathrm{g} \mathrm{ha}^{-1}\left(\mathrm{~T}_{8}\right)$ and the higher weed index was found under Sesbania (BC)+2,4-D@500 g ha-1 30 DAS $\left(\mathrm{T}_{9}\right)$ treatment. The higher gross return, net return and B:C ratio was observed under Atrazine+Pendimethalin @ 750+500 $\mathrm{g} \mathrm{ha}^{-1}\left(\mathrm{~T}_{7}\right)$. These values were very close to weed free treatment. The per cent increase in grains and stover yield was to the tune of 107.14 and 57.26 as compared to weedy check.
\end{abstract}

\section{Introduction}

Maize (Zea mays L.) is one of the most versatile emerging crops having wider adaptability under various agro-climatic conditions. It has the highest genetic yield potential among cereals and is referred to as the 'queen of cereals' (Tollenaar and Lee, 2006). It is cultivated on nearly 150 mha in about 160 countries having wider diversity of soil, climate, biodiversity and management practices that contributes $36 \%$ (782 $\mathrm{mt}$ ) in the global food grain production. In India, maize is the third most important cereal crop after rice and wheat. It is cultivated over 9.3 mha with a production and productivity of $23.70 \mathrm{mt}$ and $2557 \mathrm{~kg} \mathrm{ha}^{-1}$, respectively (Economic Survey, 2015-16). In Uttar Pradesh, it covers an area of 0.80 mha produces about $1.20 \mathrm{mt}$ with an average productivity of $1847 \mathrm{~kg} \mathrm{ha}^{-1}$ (Anonymous, 2013-14). In India, maize is predominantly used for industries, only $25 \%$ of its production is used as human food. It is an important crop in temperate climatic region as well as in semi-arid climatic region, because of the increasing demand for food and livestock feed. It contributes $6.4 \%$ to the total grain production in the country and occupies an important position in the national economy; as it is a good source of food for people, feed for poultry and fodder for livestock. Maize also produces raw materials for starch industry and is also used in the preparation of other products. The average maize crop production in India is comparatively lower to most of the other maize growing countries. Weeds are among serious constraints that limit maize production. The competition between weeds and maize is induced reducing the quality and quantity of maize yield over 30\%. In addition, weeds interfere with crop growth and yield through acquisition of required resources including light, water, nutrients and are potentially a major constraint on crop production if not controlled (John et al., 2010). Since maize is grown in rainy season, total dependence on manual or mechanical weeding at predetermined times is many times not feasible as it may coincide with showers. Therefore, use of pre-emergence herbicide followed by manual weeding can provide best option for weed suppression. Also herbicide combinations can be more useful for wide-spectrum weed 
control (Mahadi, 2014). Various factors are responsible for this lower production, among which various weeds infestation is a more important factor. More than 200 different types of weeds have been found to be infesting various crops in NPK with varying densities. The most harmful weeds, infesting maize crop and causing its yield losses in NPK are thought to be Echinocloa crus-galli (L.) P. Beauv., Leptochloa sp., Cyperus rotundus L., Sorghum helepense (L.) Pers., Cynodon dactylon (L.) Pers., Digiteria sanguinalis (L.) Scop., Convolvulus arvensis L., Tribulus terrestris L., Digera muricata(L.) Mart. and Portulaca olereacea L. (Hassan et al., 2010).

\section{Materials and Methods}

The field experiment was carried out in maize during kharif season of 2013 at the Crop Research Centre, Chirori of Sardar Vallabhbhai Patel University of Agriculture and Technology; Meerut, Uttar Pradesh (India) situated at latitude of $29^{\circ} 40^{\prime}$ $\mathrm{N}$, longitude of $77^{\circ} 42^{\prime}$ East and an altitude of $237 \mathrm{~m}$ above mean sea level. Meerut lies in the heart of Western Uttar Pradesh and has sub-tropical climate. The experimental site had an even topography with good drainage system. The soil of the experimental field was sandy loam in texture, neutral in reaction ( $\mathrm{pH} 7.70)$, and low in organic carbon $(0.52 \%)$ as well as with low available $\mathrm{N}\left(155.40 \mathrm{~kg} \mathrm{ha}^{-1}\right)$, medium in available $\mathrm{P}\left(14.76 \mathrm{~kg} \mathrm{ha}^{-1}\right)$ and medium in available $\mathrm{K}\left(139.82 \mathrm{~kg} \mathrm{ha}^{-1}\right)$ contents with normal electrical conductivity (1.65). The field experiment was laid out in RBD with three replications comprising eleven treatments of weed management which, included alachlor $1.5 \mathrm{~kg} \mathrm{ha}^{-1} \mathrm{PE}\left(\mathrm{T}_{1}\right)$; atrazine $1.0 \mathrm{~kg} \mathrm{ha}^{-1} \mathrm{PE}$ $\left(\mathrm{T}_{2}\right)$; alachlor $1.0 \mathrm{~kg} \mathrm{ha}^{-1} \mathrm{EPE}$ (15 DAS) $\left(\mathrm{T}_{3}\right)$; metrbuzin 0.75 $\mathrm{kg} \mathrm{ha}^{-1} \mathrm{PE}\left(\mathrm{T}_{4}\right)$; metrbuzin $0.25 \mathrm{~kg} \mathrm{ha}^{-1} \mathrm{EPE}$ (15 DAS) $\left(\mathrm{T}_{5}\right)$; alachlor $0.75 \mathrm{~kg} \mathrm{ha}^{-1}+$ metrbuzin $0.375 \mathrm{~kg} \mathrm{ha}^{-1}$ (tank-mix PE) $\left(\mathrm{T}_{6}\right)$; atrazine $0.75 \mathrm{~kg} \mathrm{ha}^{-1}+$ pendimethalin $0.5 \mathrm{~kg} \mathrm{ha}^{-1}$ (tankmix PE) $\left(\mathrm{T}_{7}\right)$; atrazine $0.5 \mathrm{~kg} \mathrm{ha}^{-1}+2,4-\mathrm{D} 0.5 \mathrm{~kg} \mathrm{ha}^{-1} \mathrm{POE}\left(\mathrm{T}_{8}\right)$; brown manuring (Sesbania@20 kg ha ${ }^{-1}+2,4-\mathrm{D} 0.5 \mathrm{~kg} \mathrm{ha}^{-1}$ at 30 DAS) ( $\left.\mathrm{T}_{9}\right)$; weedy check $\left(\mathrm{T}_{10}\right)$; and weed-free check $\left(\mathrm{T}_{11}\right)$. In the brown manuring with Sesbania aculeata L. treatments, Sesbania seed@20 kg ha-1 was sown by broadcasting over the entire plot at the time of sowing of maize and 2,4-D at $0.5 \mathrm{~kg} \mathrm{ha}^{-1}$ was sprayed over the Sesbania plants at 30 DAS, which were then killed and dried up gradually to serve as much and supplier of nutrients, particularly N. For tank-mix pre emergence (PE), post emergence (POE) and early post emergence (EPE) application of herbicides, required quantities of respective doses of herbicides were sprayed in the field. Maize hybrid P 3292 was sown on 23 July in 2013 with a seed rate of $20 \mathrm{~kg} \mathrm{ha}^{-1}$ in rows spaced at $60 \mathrm{~cm}$. A uniform dose of nitrogen $\left(120 \mathrm{~kg} \mathrm{ha}^{-1}\right)$, phosphorus $\left(60 \mathrm{~kg} \mathrm{ha}^{-1}\right)$ and potash $\left(40 \mathrm{~kg} \mathrm{ha}^{-1}\right)$ were applied through Urea, DAP and MOP, respectively to all the plots. A half of the total nitrogen along with total quantity of $\mathrm{P}_{2} \mathrm{O}_{5}$ and $\mathrm{K}_{2} \mathrm{O}$ was applied as basal dose.
Remaining half dose of nitrogen was top dressed equally into 2 splits at 30 days after sowing (DAS) and at ztasselling stage Thinning of excessive maize seedlings were done after 20 days of sowing to maintain a plant to plant distance of about $20 \mathrm{~cm}$. Maize received three irrigations including a pre-sowing one. Nitrogen, $\mathrm{P}$ and $\mathrm{K}$ were given in the form of urea, diammonium phosphate and muriate of potash, respectively.

\section{Results and Discussion}

Among herbicide the maximum nitrogen uptake by maize grains recorded in Alachlor+Metribuzin, being on par with Atrazine+Pendimethalin treatments produced significantly maximum nitrogen uptake by maize grains The similar findings were also reported by Sinha et al. (2005) and the maximum nitrogen uptake by maize stover recorded in Atrazine+Pendimethalin being on par with Metribuzin and Metribuzin treatments produced significantly maximum nitrogen uptake by maize Stover as compared to rest of the treatments except weed free.

Among herbicide the maximum phosphorus uptake by the maize grains found in Atrazine followed by Alachlor+Metribuzin, Metribuzin and Alachlor treatments produced significantly maximum phosphorus uptake by maize grains These findings confirm the results of Owla et al. (2015) and the maximum phosphorus uptake by the maize stover found in Metribuzin followed by Atrazine+Pendimethalin, Atrazine and Sesbania $(\mathrm{BC})+2,4-\mathrm{D}(0.5 \mathrm{~kg})$ at 30 DAS treatments produced significantly maximum phosphorus uptake by maize stover as compared to rest of the treatments, except weed free.

Among herbicide the maximum potassium uptake by maize grains fond in Metribuzin followed by Atrazine, Alachlor+Metribuzin and Atrazine+Pendimethalin treatments produced significantly maximum potassium uptake by maize grains Similar findings were also reported by Kumar et al. (2007) and the maximum potassium uptake by maize Stover fond in Atrazine+Pendimethalin followed by Atrazine, Metribuzin, Atrazine+2,4-D and treatments produced significantly maximum potassium uptake by maize stover as compared to rest of the treatments, except weed free.

The improvement in herbicidal treatments increased the grains yield $\left(\mathrm{q} \mathrm{ha}^{-1}\right)$ significantly over weedy check treatment. The maximum grains yield $\left(\mathrm{q} \mathrm{ha}^{-1}\right)$ was recorded under Atrazine + Pendimethalin being on par with Alachlor + Metribuzin, Metribuzin, Atrazine and Alachlor resulted into significantly maximum grains yield and the maximum stover yield ( $\mathrm{q} \mathrm{ha}^{-1}$ ) was recorded under Atrazine+Pendimethalin being on par with Alachlor+Metribuzin, Metribuzin and Atrazine resulted into significantly maximum grain yield Such effects of weed management practices on attributes have also been reported by Malviya and Singh (2007). These results were also supported 
by Suthar et al. (2014) and the maximum harvest index (\%) was recorded under Alachlor followed by Alachlor+Metribuzin, Metribuzin and Atrazine treatments produced significantly maximum harvest index (\%) as compared to rest of the treatments, except weed free and the maximum protein content in maize grain was found in Weed free $(8.7 \%)$ followed by Sesbania (BC)+2,4-D-500 $\mathrm{g} \mathrm{ha}^{-1} 30$ DAS over the rest of treatments. The improvement in herbicidal treatments decreased the weed index (\%) significantly over weedy check treatment. The minimum weed index (\%) was recorded under Atrazine + Pendimethalin followed by Alachlor+Metribuzin, Metribuzin and Atrazine treatments produced significantly minimum weed index (\%) as compared to rest of the treatments, except weed free (Table 1). The results are in close conformity with the findings of Shaba et al. (2015).
At harvest stage the lowest dry weight of weed was recorded in Atrazine+Pendimethalin followed by Metribuzin, Alachlor+Metribuzin and Alachlor was significantly superior to rest of the treatments except weed free. Therefore, alleviation of stress caused by weeds facilitated the crop to utilize the resources like nutrients, space and light in a better way and to produce higher yield by better expression of yield attributes and yield. The present findings is in close agreement with that of Choudhary et al. (2013). Among herbicide the maximum nitrogen content in weeds (\%) was observed in Atrazine+2,4-D followed by Sesbania (BC)+2,4-D (0.5 kg) at 30 DAS, Metribuzin and Alachlor+Metribuzin was applied and significantly higher than all remaining treatments and the maximum phosphorus content in weeds (\%) was observed in Alachlor being on par with Atrazine+2,4-D resulted into

\begin{tabular}{|c|c|c|c|c|c|c|c|c|c|c|c|}
\hline \multirow[t]{2}{*}{ Treatments } & \multicolumn{2}{|c|}{ Nitrogen } & \multicolumn{2}{|c|}{ Phosphorus } & \multicolumn{2}{|c|}{ Potassium } & \multirow{2}{*}{$\begin{array}{c}\text { Grain } \\
\text { yield } \\
(\mathrm{q} \\
\left.\mathrm{ha}^{-1}\right)\end{array}$} & \multirow{2}{*}{$\begin{array}{l}\text { Stover } \\
\text { yield } \\
(\mathrm{q} \\
\left.\mathrm{ha}^{-1}\right)\end{array}$} & \multirow{2}{*}{$\begin{array}{c}\text { Harvest } \\
\text { index } \\
(\%)\end{array}$} & \multirow{2}{*}{$\begin{array}{c}\text { Protein } \\
\text { content } \\
\text { in grain } \\
(\%)\end{array}$} & \multirow{2}{*}{$\begin{array}{c}\text { Weed } \\
\text { index } \\
(\%)\end{array}$} \\
\hline & Grains & Stover & Grains & Stover & Grains & $\overline{\text { Stover }}$ & & & & & \\
\hline Alachlor-1500 $\mathrm{g} \mathrm{ha}^{-1} \quad\left(\mathrm{~T}_{1}\right)$ & 59.43 & 38.30 & 14.50 & 09.40 & 18.25 & 75.93 & 46.8 & 67.2 & 41.0 & 7.9 & 14.3 \\
\hline Atrazine-1000 $\mathrm{g} \mathrm{ha}^{-1}\left(\mathrm{~T}_{2}\right)$ & 59.12 & 40.29 & 19.86 & 10.92 & 19.39 & 82.64 & 47.3 & 68.3 & 40.9 & 7.8 & 13.4 \\
\hline Alachlor-1000 $\mathrm{g} \mathrm{ha}^{-1}\left(\mathrm{~T}_{3}\right)$ & 52.22 & 37.87 & 16.72 & 07.83 & 17.54 & 75.74 & 40.8 & 65.3 & 38.4 & 8.0 & 25.3 \\
\hline Metribuzin-750 $\mathrm{g} \mathrm{ha}^{-1}\left(\mathrm{~T}_{4}\right)$ & 60.35 & 42.57 & 16.28 & 13.26 & 21.55 & 84.45 & 47.9 & 69.8 & 40.6 & 7.9 & 12.3 \\
\hline Metribuzin-250 $\mathrm{g} \mathrm{ha}^{-1}\left(\mathrm{~T}_{5}\right)$ & 51.60 & 42.36 & 17.34 & 10.59 & 16.07 & 57.10 & 42.3 & 66.2 & 38.9 & 7.6 & 22.5 \\
\hline $\begin{array}{l}\text { Alachlor+Metribuzin - } \\
750+375 \mathrm{~g} \mathrm{ha}^{-1}\left(\mathrm{~T}_{6}\right)\end{array}$ & 63.08 & 40.41 & 18.58 & 10.63 & 19.07 & 72.31 & 48.9 & 70.9 & 40.8 & 8.0 & 10.4 \\
\hline $\begin{array}{l}\text { Atrazine+Pendimethalin- } \\
750+500 \mathrm{~g} \mathrm{ha}^{-1}\left(\mathrm{~T}_{7}\right)\end{array}$ & 62.61 & 43.42 & 16.26 & 12.51 & 20.70 & 88.32 & 49.3 & 73.6 & 40.1 & 7.9 & 09.7 \\
\hline $\begin{array}{l}\text { Atrazine+2,4-D-500+500 g } \\
\text { ha }^{-1}\left(\mathrm{~T}_{8}\right)\end{array}$ & 54.82 & 41.23 & 13.60 & 09.31 & 16.15 & 80.46 & 42.5 & 66.5 & 38.9 & 8.0 & 22.2 \\
\hline $\begin{array}{l}\text { Sesbania (BC)+2,4-D -500 } \\
\mathrm{g} \mathrm{ha}^{-1} 30 \mathrm{DAS}\left(\mathrm{T}_{9}\right)\end{array}$ & 55.15 & 39.70 & 15.15 & 11.44 & 15.57 & 80.08 & 42.1 & 67.3 & 38.4 & 8.2 & 22.9 \\
\hline Weedy check $\left(\mathrm{T}_{10}\right)$ & 26.65 & 22.46 & 08.33 & 05.61 & 06.42 & 51.48 & 23.8 & 46.8 & 33.7 & 7.0 & 56.4 \\
\hline Weed free $\left(\mathrm{T}_{11}\right)$ & 75.89 & 54.81 & 26.75 & 14.66 & 25.66 & 104.9 & 54.6 & 77.2 & 41.4 & 8.7 & 00.0 \\
\hline $\operatorname{SEm} \pm$ & 0.68 & 0.43 & 0.26 & 0.14 & 0.27 & 0.83 & 1.34 & 2.03 & 0.06 & _ & 0.12 \\
\hline $\mathrm{CD}(p=0.05)$ & 2.04 & 1.28 & 0.77 & 0.43 & 0.82 & 2.47 & 3.99 & 6.03 & 0.20 & - & 0.38 \\
\hline
\end{tabular}

significantly maximum phosphorus content in weed as compared to rest of the treatments and the maximum potassium content in weeds (\%) was observed in Atrazine+2,4-D followed by Sesbania (BC)+2,4-D (0.5 kg) at $30 \mathrm{DAS}$, Alachlor and Metribuzin was applied and significantly higher than all remaining treatments, except weedy check. These results might be due to effective weed control resulting in lower weed density as well as nutrient uptake in the respective weed control methods. The results confirm the findings of Mundra et al. (2002).
Among herbicide the maximum nitrogen uptake by weed $(\mathrm{kg}$ $\mathrm{ha}^{-1}$ ) was observed in Atrazine+2,4-D followed by Sesbania (BC)+2,4-D (0.5 kg) at $30 \mathrm{DAS}$, Metribuzin and Alachlor was applied and significantly higher than all remaining treatments and the maximum phosphorus uptake by weed $\left(\mathrm{kg} \mathrm{ha}^{-1}\right)$ was observed in Atrazine+2,4-D followed by Sesbania (BC)+2,4-D $(0.5 \mathrm{~kg})$ at $30 \mathrm{DAS}$, Metribuzin and Alachlor was applied and significantly higher than all remaining treatments and maximum potassium uptake by weed $\left(\mathrm{kg} \mathrm{ha}^{-1}\right)$ was observed 
in Atrazine+2,4-D followed by Sesbania (BC)+2,4-D (0.5 $\mathrm{kg}$ ) at $30 \mathrm{DAS}$, Metribuzin and Alachlor was applied and significantly higher than all remaining treatments, except weedy check. These results confirm the findings of Chaudhari et al. (2007). The improvement in herbicidal treatments decreased the weed index (\%) significantly over weedy check treatment. The minimum weed index (\%) was recorded under Atrazine+Pendimethalin followed by Alachlor+Metribuzin, Metribuzin and Atrazine treatments produced significantly minimum weed index (\%) as compared to rest of the treatments, except weed free.
Among the herbicidal treatment maximum cost of cultivation was recorded in Sesbania (BC)+2,4-D $(0.5 \mathrm{~kg})$ at 30 DAS (₹ $23045 \mathrm{ha}^{-1}$ ) followed by Alachlor (₹ $22065 \mathrm{ha}^{-1}$ ), Alachlor+Metribuzin ( $₹ 21695 \mathrm{ha}^{-1}$ ) and Alachlor (₹ $221605 \mathrm{ha}^{-}$ $\left.{ }^{1}\right)$ treated plots. The higher gross return was observed in weed free plots (₹ $86966 \mathrm{ha}^{-1}$ ) followed by Atrazine+Pendimethalin (₹ $79303 \mathrm{ha}^{-1}$ ). The maximum net return of (₹ $56095 \mathrm{ha}^{-1}$ ) was obtained with the application of Atrazine+Pendimethalin, followed by Alachlor+Metribuzin ( $₹ 54339 \mathrm{ha}^{-1}$ ) and the maximum benefit:cost ratio (2.68) was found in Atrazine+Pendimethalin treated plots (Table 2).

Table 2: Effect of various weed management practices on Nutrient content (\%) and uptake $\left(\mathrm{kg} \mathrm{ha}^{-1}\right)$ in weed and economics of maize

\begin{tabular}{|c|c|c|c|c|c|c|c|c|c|c|c|}
\hline \multirow[t]{2}{*}{ Treatment } & \multirow{2}{*}{$\begin{array}{l}\text { Weed dry } \\
\text { weight } \\
\left(\mathrm{g} \mathrm{m}^{-2}\right) \text { at } \\
60 \text { days }\end{array}$} & \multicolumn{3}{|c|}{$\begin{array}{l}\text { Nutrient content } \\
(\%)\end{array}$} & \multicolumn{3}{|c|}{$\begin{array}{l}\text { Nutrient uptake } \\
\quad\left(\mathrm{kg} \mathrm{ha}^{-1}\right)\end{array}$} & \multicolumn{4}{|c|}{ Economics of maize } \\
\hline & & $\mathrm{N}$ & $\mathrm{P}$ & K & $\mathrm{N}$ & $\mathrm{P}$ & K & $\begin{array}{l}\text { Cost of } \\
\text { cultivation } \\
\left(₹ \mathrm{ha}^{-1}\right)\end{array}$ & $\begin{array}{l}\text { Gross } \\
\text { return } \\
\left(₹ h^{1}\right) \\
\end{array}$ & $\begin{array}{l}\text { Net } \\
\text { return } \\
\left(₹ \mathrm{ha}^{1}\right)\end{array}$ & $\begin{array}{l}\text { Benefit } \\
\text { cost ratio }\end{array}$ \\
\hline Alachlor-1500 $\mathrm{g} \mathrm{ha}^{-1}\left(\mathrm{~T}_{1}\right)$ & $6.1(36.3)$ & 0.98 & 0.15 & 1.23 & 3.5 & 0.5 & 4.4 & 22065 & 74748 & 52683 & 2.38 \\
\hline Atrazine-1000 $\mathrm{g} \mathrm{ha}^{-1}\left(\mathrm{~T}_{2}\right)$ & $6.3(38.9)$ & 0.94 & 0.20 & 1.31 & 3.6 & 0.8 & 5.1 & 21565 & 75623 & 54058 & 2.50 \\
\hline Alachlor-1000 $\mathrm{g} \mathrm{ha}^{-1}\left(\mathrm{~T}_{3}\right)$ & $6.9(46.8)$ & 1.07 & 0.32 & 1.40 & 5.0 & 1.5 & 6.5 & 21605 & 66120 & 44515 & 2.06 \\
\hline Metribuzin-750 $\mathrm{g} \mathrm{ha}^{-1}\left(\mathrm{~T}_{4}\right)$ & $5.9(34.2)$ & 0.92 & 0.19 & 1.19 & 3.1 & 0.6 & 4.1 & 21425 & 76709 & 55248 & 2.58 \\
\hline Metribuzin-250 $\mathrm{g} \mathrm{ha}^{-1}\left(\mathrm{~T}_{5}\right)$ & $6.8(45.3)$ & 1.10 & 0.29 & 1.32 & 5.0 & 1.3 & 5.9 & 21055 & 68653 & 47598 & 2.22 \\
\hline $\begin{array}{l}\text { Alachlor+Metribuzin } \\
-750+375 \mathrm{~g} \mathrm{ha}^{-1}\left(\mathrm{~T}_{6}\right)\end{array}$ & $6.0(35.4)$ & 1.01 & 0.28 & 1.29 & 3.5 & 1.0 & 4.5 & 21695 & 78239 & 56544 & 2.60 \\
\hline $\begin{array}{l}\text { Atrazine+Pendimethalin } \\
-750+500 \mathrm{~g} \mathrm{ha}^{-1}\left(\mathrm{~T}_{7}\right)\end{array}$ & $5.4(28.6)$ & 0.90 & 0.21 & 1.02 & 2.5 & 0.6 & 2.9 & 21540 & 79303 & 57763 & 2.68 \\
\hline $\begin{array}{l}\text { Atrazine+2,4-D-500+500 } \\
\mathrm{g} \mathrm{ha}^{-1}\left(\mathrm{~T}_{8}\right)\end{array}$ & $9.0(81.2)$ & 1.29 & 0.31 & 1.83 & 10.4 & 2.5 & 14.8 & 21495 & 68975 & 47480 & 2.20 \\
\hline $\begin{array}{l}\text { Sesbania }(\mathrm{BC})+2,4- \\
\mathrm{D}-500 \mathrm{~g} \mathrm{ha}^{-1} 30 \mathrm{DAS}\left(\mathrm{T}_{9}\right)\end{array}$ & $8.3(68.3)$ & 1.19 & 0.29 & 1.72 & 8.1 & 2.0 & 11.7 & 23045 & 68611 & 45566 & 1.97 \\
\hline Weedy check $\left(\mathrm{T}_{10}\right)$ & $\begin{array}{c}13.9 \\
(193.5)\end{array}$ & 1.84 & 0.34 & 1.96 & 35.6 & 6.5 & 37.9 & 20265 & 40538 & 20273 & 1.00 \\
\hline Weed free $\left(T_{11}\right)$ & 00 & 0.00 & 0.00 & 0.00 & 0.00 & 0.00 & 0.00 & 27765 & 86966 & 59201 & 2.13 \\
\hline $\operatorname{SEm} \pm$ & 0.09 & 0.02 & 0.006 & 0.03 & 0.56 & 0.10 & 0.60 & - & - & - & - \\
\hline $\mathrm{CD}(p=0.05)$ & 0.28 & 0.07 & 0.017 & 0.09 & 1.67 & 0.30 & 1.79 & - & - & - & - \\
\hline
\end{tabular}

\section{Conclusion}

It can be concluded from the investigations that maximum $\mathrm{N}$ and $\mathrm{P}$ uptake in maize grains was revealed with Alachlor+Metribuzin@750+375 g ha ${ }^{-1}\left(\mathrm{~T}_{6}\right)$ and the maximum $\mathrm{K}$ uptake by maize grains was observed with Atrazine+Pendimethalin @ 750+500 $\mathrm{g} \mathrm{ha}^{-1}\left(\mathrm{~T}_{7}\right)$ as compared to rest of the treatments. The maximum $\mathrm{N}, \mathrm{P}$ and $\mathrm{K}$ uptake in maize stover was observed with Atrazine+Pendimethalin (a) 750+500 $\mathrm{g} \mathrm{ha}^{-1}\left(\mathrm{~T}_{7}\right)$ along with grain yield $\left(\mathrm{q} \mathrm{ha}^{-1}\right)$, stover yield $\left(\mathrm{q} \mathrm{ha}^{-1}\right)$, harvest index, gross return, net return as well as $\mathrm{B}: \mathrm{C}$ ratio, respectively. These values were very close to weed free treatment.

\section{References}

Anonymous, 2013-14. Ministry of Agriculture. Department of agriculture and cooperation.

Chaudhari, A.P., Gaikwad, C.B., Tiwari, T.K., Nikam, A.S., Bhende, S.N., Bagwan, I.R., 2007. Effect of weed control on nutrient uptake, weed weight and yield of groundnut, 
International Journal of Agricultural Sciences 3(1), 193-195

Choudhary, P., Nepalia, V., Singh, D., 2013. Effect of weed control and sulphur on productivity of quality protein maize (Zea mays L.), dynamics of associated weeds and relative nutrient uptake, Indian Journal of Agronomy 58(3), 535-538

Economic Survey, 2015-2016. Directorate of Economics \& Statistics, Department of Agriculture \& Co-operation, Ministry of Agriculture and Farmers Welfare, New Delhi.

Hassan, G., Tanveer, S., Khan, N.U., Munir, M., 2010. Integrating cultivars with reduced herbicides rates for weed management in maize, Pakistan Journal of Botany 42(3), 1923-1929.

John, R.T., Michal, A.C., 2010. Subplots facilitate assessment of corn yield losses from weed competition in a long term experiment, Agronomy for sustainable development 30, 445-453.

Kumar, D., Kumar, G.S., Jeyasrinivas, R., 2007. Effect of different weed management practices on nutrient uptake by weeds and maize, Journal of Eco-biology 21(4), 333-338. (Mar.), 215-220.

Malviya, A., Singh, B., 2007. Weed dynamics, productivity and economics of maize (zea mays) as affected by integrated weed management under rainfed condition. Indian Journal of Agronomy 52(4), 321-324.

Mahadi, M.A., 2014. Growth, nutrient uptake and yield of maize (Zea mays L.) as influenced by weed control and poultry manure, International Journal of Science and Nature 5 (1), 94-102.

Mundra, S.L., Vyas, A.K., Maliwal, P.L., 2002. Effect of weed and nutrient management on nutrient uptake by maize (Zea mays) and weeds. Indian Journal of Agronomy 47(3), 378-383.

Owla, M.L., Nepalia, V., Chouhan, G.S., Singh, D., 2015. Effect of fertility levels, nutrient sources and weed control on weed dynamics and yield of quality protein maize (Zea mays L.) and relative nitrogen and phosphorus uptake, Indian Journal of Agronomy,60(2), 267-272.

Shaba, S.A., Yehia, Z.R., Safina, S.A., Abo El-Hassan, R.G., 2015. Effect of some maize herbicides on weeds and yield and residual effect on some following crops (Wheat and Broad bean), American Eurasian Journal of Agricultural and environmental Science 15(6), 1004-1011.

Sinha, S.P., Prasad, S.M., Singh, S.J., 2005. Nutrient utilization by winter maize (Zea mays) and weeds as influenced by integrated weed management. Indian Journal of Agronomy 50(4), 303-304.

Suthar, M., Singh, D., Nepalia, V., Singh, A.K., 2014. Performance of sweet corn (Zea mays L.) varieties under varying fertility levels. Indian Journal of agronomy 59 (1), 168-70.

Tollenaar, M., Lee, E.A., 2006. Dissection of physiological processes underlying grain yield in maize by examining genetic improvement and heterosis. Maydica 51, 399-408. 